\title{
PERBEDAAN SINDROM METABOLIK PADA WANITA VEGETARIAN TIPE VEGAN DAN NON VEGAN
}

\author{
Diah Ari Setiyani, Yekti Wirawanni*) \\ Program Studi Ilmu Gizi Fakultas Kedokteran Universitas Diponegoro \\ Jl.Dr.Sutomo No.14, Semarang, Telp (024) 8453708, Email : gizifk@undip.ac.id
}

\begin{abstract}
Background: The metabolic syndrome is a cluster of metabolic disorders that are associated with a heightened risk of cardiovascular disease. Vegetarian diet especially vegan may play a role in decreasing the risk of metabolic syndrome, but other study showed that risk of metabolic syndrome in vegan higher than non vegan. The objective of this study was to understand the difference of metabolic syndrome in women vegetarian between vegan and non vegan.

Design: The study was done with cross sectional study design. The subjects of this study consist of 18 vegan and 18 non vegan who was selected by consecutive sampling. Characteristic of subjects, physical activity, and dietary nutrient intake were collected by interviewing. Waist circumference was measured with a non stretchable tape, while blood pressure was measured by sphygmomanometer. Blood samples were also taken to measure HDLcholesterol, triglyceride, and fasting blood glucose concentration.

Result: This study showed 11,1\% subjects both on vegan and non vegan had metabolic syndrome. Vegan had lower means for waist circumference, blood pressure, triglyceride and fasting blood glucose concentration, and higher mean for HDL-cholesterol than non vegan. There were no differences of metabolic syndrome in women vegetarian between vegan and non vegan.

Conclusions: No differences of metabolic syndrome in women vegetarian between vegan and non vegan. Vegan had lower means for all components of the metabolic syndrome, except HDL-cholesterol.
\end{abstract}

Keyword: vegan; non vegan; metabolic syndrome

\section{ABSTRAK}

Latar Belakang: Sindrom metabolik adalah kumpulan kelainan metabolik yang dikaitkan dengan peningkatan risiko penyakit kardiovaskular. Diet vegetarian terutama vegan dapat berperan dalam penurunan risiko sindrom metabolik, tetapi masih didapatkan penelitian yang menyatakan bahwa vegan berisiko sindrom metabolik bahkan lebih tinggi daripada non vegan. Penelitian ini bertujuan untuk mengetahui perbedaan sindrom metabolik pada wanita vegetarian vegan dan non vegan.

Metode: Penelitian ini dilakukan dengan desain cross sectional. Subjek penelitian terdiri dari 18 vegan dan 18 non vegan yang dipilih secara consecutive sampling. Pengumpulan data karakteristik subjek, aktivitas fisik, dan asupan zat gizi dengan wawancara. Data lingkar pinggang menggunakan pita ukur, sedangkan tekanan darah menggunakan sphygmomanometer. Pengambilan darah dilakukan untuk pengukuran kadar kolesterol HDL, kadar trigliserida, dan kadar glukosa darah puasa.

Hasil: Pada penelitian ini terdapat 11,1\% subjek baik pada vegan maupun non vegan yang mengalami sindrom metabolik. Rerata lingkar pinggang, kadar trigliserida, tekanan darah, dan kadar glukosa darah puasa vegan lebih rendah serta kadar kolesterol HDL lebih tinggi dibanding non vegan. Tidak terdapat perbedaan kejadian sindrom metabolik antara wanita vegetarian vegan dan non vegan.

Simpulan: Tidak terdapat perbedaan sindrom metabolik antara wanita vegetarian tipe vegan dan non vegan. Namun, semua komponen sindrom metabolik pada vegan lebih rendah dibanding non vegan, kecuali kadar kolesterol HDL.

Kata Kunci: vegan; non vegan; sindrom metabolik

\section{PENDAHULUAN}

Vegetarian telah menjadi salah satu pilihan gaya hidup masyarakat di berbagai negara, termasuk Indonesia. Pada saat berdiri tahun 1998, jumlah vegetarian yang terdaftar pada Indonesia Vegetarian Society (IVS) sekitar 5.000 anggota dan meningkat menjadi 60.000 anggota pada tahun 2007. ${ }^{1}$ Angka ini merupakan sebagian kecil dari jumlah yang sesungguhnya karena tidak semua vegetarian mendaftar menjadi anggota. Gaya hidup vegetarian mengutamakan asupan yang berasal dari nabati daripada hewani beserta olahannya. ${ }^{2}$ 
Beragam alasan yang melatarbelakangi seseorang menjadi vegetarian, mulai dari faktor agama sampai dengan faktor kesehatan. ${ }^{3}$

Sindrom metabolik adalah kumpulan kelainan metabolik yang dikaitkan dengan peningkatan risiko penyakit kardiovaskular. ${ }^{4}$ Menurut kriteria dari National Cholesterol Education Program Third Adult Treatment Panel (NCEP-ATP III), seseorang dikatakan mengalami sindrom metabolik apabila terdapat sedikitnya tiga dari lima komponen yang terdiri dari obesitas sentral, hipertensi, penurunan kadar kolesterol HDL (high density lipoprotein), peningkatan kadar trigliserida, dan peningkatan glukosa darah puasa. ${ }^{5}$ National Health and Nutrition Examination Survey (NHANES) 2003-2006 di Amerika Serikat mendapatkan sekitar $34 \%$ dari populasi dewasa (usia >20 tahun) memenuhi kriteria tersebut. ${ }^{6}$ Sementara perbandingan NHANES III (1988-1994) dan NHANES (1999-2000) mendapatkan prevalensi menurut usia meningkat menjadi $23,5 \%$ pada wanita dan $2,2 \%$ pada pria. ${ }^{7} \mathrm{Di}$ Indonesia, penelitian di Bali (2003-2009) mendapatkan prevalensi yang lebih besar pada wanita yaitu $20 \%$, sedangkan pada pria $16,6 \%{ }^{8}$

Diet telah dilaporkan menjadi salah satu faktor yang mempengaruhi sindrom metabolik. Secara teori, diet vegetarian rendah lemak total, lemak jenuh, dan kolesterol. Selain itu, tinggi lemak tidak jenuh, karbohidrat kompleks, protein nabati, dan serat. ${ }^{2}$ Hal ini menyebabkan vegetarian mempunyai risiko yang rendah terhadap sindrom metabolik. Sementara untuk natrium, tidak ada fakta konsisten yang menunjukkan bahwa vegetarian memiliki asupan natrium yang rendah, karena beberapa makanan vegetarian juga tinggi natrium. ${ }^{2}$ Lama seseorang menjadi vegetarian dan aktivitas fisik juga dapat berpengaruh terhadap sindrom metabolik. ${ }^{9}$

Penelitian di Amerika menunjukkan bahwa diet vegetarian memiliki kadar kolesterol HDL yang lebih tinggi, dan kadar trigliserida, tekanan darah, kadar glukosa darah puasa, lingkar pinggang, serta risiko sindrom metabolik yang lebih rendah dibanding non vegetarian (mereka yang mengkonsumsi makanan hewani). ${ }^{10}$ Namun, vegetarian dapat dibagi menjadi vegan (sama sekali tidak mengkonsumsi makanan hewani beserta olahannya) dan non vegan (mereka yang masih mengkonsumsi susu, telur, ataupun keduanya), dimana berbagai tipe vegetarian ini mungkin akan memberikan manfaat kesehatan yang berbeda. Penelitian di Taiwan menunjukkan bahwa diet lakto-ovo vegetarian (non vegan) dan diet non vegetarian memiliki risiko sindrom metabolik yang lebih rendah dibanding diet vegetarian tipe vegan. ${ }^{11}$ Hasil serupa diamati pada penelitian Gary Fraser yang menemukan bahwa diet vegetarian tipe vegan tidak memberikan manfaat yang signifikan terhadap penyakit kronik, seperti penyakit kardiovaskular dan diabetes, dibandingkan diet vegetarian tipe lainnya. ${ }^{12}$ Penelitian ini bertujuan untuk mengetahui perbedaan sindrom metabolik pada wanita vegetarian yang dibedakan menjadi vegetarian tipe vegan (vegetarian murni) dan non vegan (lakto, ovo, dan lakto-ovo vegetarian).

\section{METODA}

Penelitian ini termasuk dalam lingkup gizi masyarakat dan merupakan penelitian observasional dengan desain cross sectional. Penelitian dilaksanakan pada bulan Juni sampai Juli 2012 di IVS Surabaya dan Semarang, serta komunitas Suma Ching Hai (komunitas yang menerapkan diet vegetarian) Yogyakarta.

Populasi terjangkau dalam penelitian ini adalah wanita vegetarian di Surabaya, Semarang, dan Yogyakarta. Besar subjek yang digunakan sebanyak 36 orang dengan masing-masing kelompok sebanyak 18 orang. Besar subjek penelitian dihitung dengan menggunakan rumus perkiraan besar sampel untuk beda rerata dua kelompok independen dengan tingkat kemaknaan $\left(Z_{\alpha}\right) 95 \%$, tingkat kekuatan uji $\left(Z_{\beta}\right) 1,64$, simpang baku kedua kelompok (S) $9,52,{ }^{11}$ dan perbedaan klinis yang diinginkan $\left(\mathrm{x}_{1}-\mathrm{x}_{2}\right) \quad 13,04 .{ }^{13}$ Pengambilan subjek penelitian dilakukan dengan teknik consecutive sampling dengan kriteria inklusi yaitu subjek berjenis kelamin wanita, tidak sedang hamil, tidak mempunyai kebiasaan merokok, tidak mempunyai kebiasaan mengkonsumsi alkohol, tidak mempunyai riwayat penyakit kronik degeneratif, dan tidak mengkonsumsi obat-obatan anti-hiperlipidemia atau anti-hipertensi, serta bersedia diambil sampel darahnya.

Data yang dikumpulkan antara lain karakteristik subjek penelitian, asupan karbohidrat, protein, lemak, kolesterol, Poly Unsaturated Fatty Acid (PUFA), Mono Unsaturated Fatty Acid (MUFA), Saturated Fatty Acid (SFA), serat, natrium, aktivitas fisik, lingkar pinggang, kadar kolesterol HDL, kadar trigliserida, tekanan darah, dan kadar glukosa darah puasa. Data karakteristik subjek meliputi usia, lama menjadi vegetarian, dan tipe vegetarian diperoleh melalui kuesioner. Subjek 
dikategorikan menjadi vegan apabila sama sekali tidak mengkonsumsi produk hewani beserta olahannya dan non vegan apabila masih mengkonsumsi susu, telur maupun produk makanan yang mengandung bahan tersebut. Usia dibedakan menjadi 20-39 tahun, 40-59 tahun, dan $\geq 60$ tahun berdasarkan rekomendasi NHANES. ${ }^{6}$ Lama menjadi vegetarian dibedakan menjadi $<6$ tahun, 6-11 tahun, dan > 11 tahun. ${ }^{14}$ Data asupan diperoleh melalui formulir Food Frequency Semi Quantitative, kemudian dihitung rerata konsumsi perhari dan diolah menggunakan program nutrisurvey. Aktivitas fisik diukur dengan International Physical Activity Questionaire (IPAQ) yang dinyatakan dalam METmenit/minggu. Hasil data aktivitas fisik dinilai dengan mengkalikan koefisien jenis aktivitas fisik dengan frekuensi aktivitas tersebut dalam seminggu dan dengan menit yang digunakan untuk beraktivitas, kemudian dikategorikan rendah apabila skor total < 600 MET-menit/minggu, sedang apabila 600-1499 MET-menit/minggu, dan tinggi apabila $\geq 1500 \mathrm{MET}$-menit/minggu. ${ }^{15}$

Data lingkar pinggang diperoleh dari pengukuran langsung menggunakan pita ukur berkapasitas $150 \mathrm{~cm}$ dengan ketelitian $0,1 \mathrm{~cm}$. Lingkar pinggang diukur pada pertengahan antara batas bawah tulang iga dan krista iliaka dengan menggunakan pita ukur secara horizontal pada saat akhir respirasi normal dengan kedua tungkai dilebarkan 20-30 cm dan subjek diminta untuk tidak menahan perutnya. ${ }^{16}$ Tekanan darah diukur oleh petugas kesehatan setelah subjek duduk selama 5 menit dengan menggunakan sphygmomanometer yang dilakukan sebanyak 2 kali dengan interval 1 menit. Kadar kolesterol HDL, kadar trigliserida, dan kadar glukosa darah puasa diukur oleh petugas laboratorium klinik setelah subjek berpuasa minimal 8 jam menggunakan alat cobas mira analyzer dengan metode tes warna enzimatik untuk kadar kolesterol HDL dan trigliserida, serta metode GDO-PAP untuk kadar glukosa darah puasa. ${ }^{5}$

Data yang sudah diperoleh kemudian dianalisis secara statistik. Analisis univariat dilakukan untuk mendeskripsikan data karakteristik subjek, aktivitas fisik, asupan, lingkar pinggang, kadar kolesterol HDL, kadar trigliserida, tekanan darah, dan kadar glukosa darah puasa, yang dibedakan berdasarkan tipe vegetarian. Data tersebut kemudian diuji kenormalannya dengan uji Shapiro-Wilk. Analisis bivariat dengan uji beda independent $t$-test dan uji Mann-Whitney, serta uji beda Kolmogorov-Smirnov yang digunakan untuk mengetahui perbedaan sindrom metabolik antara wanita vegetarian vegan dan non vegan. ${ }^{17}$

\section{HASIL PENELITIAN}

\section{Karakteristik Subjek Penelitian}

Karakteristik subjek penelitian dapat dilihat pada tabel 1.

Tabel 1. Karakteristik subjek penelitian menurut usia, lama menjadi vegetarian, dan aktivitas fisik

\begin{tabular}{|c|c|c|c|c|}
\hline \multirow[t]{2}{*}{ Karakteristik } & \multicolumn{2}{|c|}{$\begin{array}{l}\text { Vegetarian Vegan } \\
\qquad(n=18)\end{array}$} & \multicolumn{2}{|c|}{$\begin{array}{c}\text { Vegetarian Non Vegan } \\
\qquad(\mathrm{n}=18)\end{array}$} \\
\hline & $\mathrm{n}$ & $\%$ & $\mathrm{n}$ & $\%$ \\
\hline \multicolumn{5}{|l|}{ Usia } \\
\hline 20-39 tahun & 9 & 50,0 & 9 & 50,0 \\
\hline 40-59 tahun & 6 & 33,3 & 7 & 38,9 \\
\hline$\geq 60$ tahun & 3 & 16,7 & 2 & 11,1 \\
\hline Total & 18 & 100,0 & 18 & 100,0 \\
\hline \multicolumn{5}{|c|}{ Lama menjadi vegetarian } \\
\hline$<6$ tahun & 15 & 83,3 & 1 & 5,6 \\
\hline $6-11$ tahun & 2 & 11,1 & 3 & 16,7 \\
\hline$>11$ tahun & 1 & 5,6 & 14 & 77,8 \\
\hline Total & 18 & 100,0 & 18 & 100,0 \\
\hline \multicolumn{5}{|l|}{ Aktivitas fisik } \\
\hline Rendah & 7 & 38,9 & 3 & 16,7 \\
\hline Sedang & 6 & 33,3 & 6 & 33,3 \\
\hline Tinggi & 5 & 27,8 & 9 & 50,0 \\
\hline Total & 18 & 100,0 & 18 & 100,0 \\
\hline
\end{tabular}


Berdasarkan hasil penelitian, diketahui bahwa separuh (50\%) usia subjek berkisar antara 20-39 tahun. Sebagian besar $(83,3 \%)$ subjek vegan baru menjalankan diet vegan kurang dari 6 tahun, sedangkan pada sebagian besar $(77,8 \%)$ subjek non vegan telah menjalankan diet vegetarian selama lebih dari 11 tahun. Diet non vegan dianggap lebih mudah untuk diterapkan dibanding vegan, karena non vegan masih dapat mengkonsumsi produk yang mengandung susu dan telur, sehingga pemilihan makanan saat di luar rumah lebih bervariasi. Skor aktivitas fisik pada sebagian subjek non vegan tergolong tinggi.

Nilai rerata, simpang baku, dan hasil uji beda dapat dilihat pada tabel 2 .

Tabel 2. Nilai rerata, simpang baku, dan hasil uji beda karakteristik subjek

\begin{tabular}{lccc}
\hline Variabel & $\begin{array}{c}\text { Vegetarian Vegan } \\
(\mathrm{n}=18)\end{array}$ & $\begin{array}{c}\text { Vegetarian Non Vegan } \\
(\mathrm{n}=18)\end{array}$ & \multirow{2}{*}{$p$} \\
\cline { 2 - 3 } & Rerata \pm SB & Rerata \pm SB & 0,727 \\
\hline Usia (th) & $39,67 \pm 15,47$ & $41,39 \pm 13,89$ & $0,000 * *$ \\
$\begin{array}{l}\text { Lama menjadi } \\
\text { vegetarian (th)* }\end{array}$ & $4,19 \pm 3,91$ & $17,47 \pm 11,98$ & \\
$\begin{array}{l}\text { Skor aktivitas } \\
(\text { MET- }\end{array}$ & $1455,17 \pm 1467,69$ & $2024,31 \pm 1390,8$ & 0,114 \\
menit/minggu)* & & & \\
\hline Hasil uji independent t-test. $*$ Uji Mann-Whitney. **Signifikan $(\mathrm{p}<0,001)$. &
\end{tabular}

Terdapat perbedaan lama menjadi vegetarian antara vegan dan non vegan $(p<0,001)$ dengan ratarata $4,19 \pm 3,91$ tahun untuk vegan dan $17,47 \pm 11,98$ tahun untuk non vegan. Tidak terdapat perbedaan usia $(p=0,727)$ dan skor aktivitas fisik $(p=0,114)$ antara vegan dan non vegan. Namun secara deskriptif, rerata usia dan aktivitas fisik non vegan lebih tinggi daripada vegan.

\section{Asupan Zat Gizi Subjek}

Perbedaan asupan zat gizi subjek dapat dilihat pada tabel 3 .

Tabel 3. Hasil uji beda asupan karbohidrat, protein, lemak, kolesterol, SFA, MUFA, PUFA, serat, dan natrium subjek

\begin{tabular}{lccc}
\hline Asupan Zat Gizi & $\begin{array}{c}\text { Vegetarian Vegan } \\
(\mathrm{n}=18)\end{array}$ & $\begin{array}{c}\text { Vegetarian Non Vegan } \\
(\mathrm{n}=18)\end{array}$ & $p$ \\
\cline { 2 - 3 } & Rerata \pm SB & Rerata \pm SB & 0,449 \\
\hline Karbohidrat & $264,07 \pm 713,55$ & $239,05 \pm 76,25$ & \\
(gr)* & $54,11 \pm 36,73$ & $41,12 \pm 19,97$ & 0,117 \\
Protein (gr) & $34,16 \pm 21,99$ & $27,81 \pm 12,39$ & 0,669 \\
Lemak (gr) & 0 & $31,64 \pm 56,86$ & $0,000^{* *}$ \\
Kolesterol (mg) & $11,28 \pm 9,74$ & $7,04 \pm 5,04$ & 0,128 \\
PUFA (gr) & $7,61 \pm 6,71$ & $5,94 \pm 4,14$ & 0,716 \\
MUFA (gr) & $12,42 \pm 6,29$ & $12,85 \pm 5,31$ & 0,825 \\
SFA (gr)* & $24,52 \pm 15,74$ & $19,84 \pm 9,05$ & 0,527 \\
Serat (gr) & $111,52 \pm 85,88$ & $112,38 \pm 75,76$ & 0,569 \\
Natrium (mg) & &
\end{tabular}

Hasil uji Mann-Whitney. * Uji independent t-test. **Signifikan $(\mathrm{p}<0,001)$.

Berdasarkan hasil penelitian, diketahui bahwa rerata asupan karbohidrat, protein, lemak total, PUFA, MUFA, SFA, serat, dan natrium antara subjek vegan dan non vegan tidak jauh berbeda. Perbedaan yang bermakna hanya terlihat pada asupan kolesterol $(p<0,001)$, dimana pada subjek vegan sama sekali tidak ditemukan adanya asupan makanan yang mengandung kolesterol. Namun asupan PUFA, MUFA dan serat yang memiliki 
efek protektif terhadap sindrom metabolik secara deskriptif ditemukan lebih tinggi pada vegan.

\section{Perbedaan Sindrom Metabolik}

Sindrom metabolik terdiri dari lima komponen yaitu lingkar pinggang, kadar kolesterol
HDL, kadar trigliserida, tekanan darah, dan kadar glukosa darah puasa. Distribusi frekuensi komponen sindrom metabolik subjek yang dibedakan menjadi vegan dan non vegan dapat dilihat pada tabel 4 .

Tabel 4. Distribusi frekuensi komponen sindrom metabolik antara vegan dan non vegan

\begin{tabular}{|c|c|c|c|c|}
\hline \multirow[t]{2}{*}{$\begin{array}{l}\text { Komponen sindrom } \\
\text { metabolik }\end{array}$} & \multicolumn{2}{|c|}{$\begin{array}{c}\text { Vegetarian Vegan } \\
(n=18)\end{array}$} & \multicolumn{2}{|c|}{$\begin{array}{c}\text { Vegetarian Non Vegan } \\
\qquad(\mathrm{n}=18)\end{array}$} \\
\hline & $\mathrm{n}$ & $\%$ & $\mathrm{n}$ & $\%$ \\
\hline \multicolumn{5}{|l|}{ Lingkar pinggang } \\
\hline Normal $<80 \mathrm{~cm}$ & 11 & 61,1 & 7 & 38,9 \\
\hline Obesitas sentral $\geq 80 \mathrm{~cm}$ & 7 & 38,9 & 11 & 61,1 \\
\hline \multicolumn{5}{|l|}{ Kadar kolesterol HDL } \\
\hline Rendah < $50 \mathrm{mg} / \mathrm{dl}$ & 4 & 22,2 & 5 & 27,8 \\
\hline Normal $\geq 50 \mathrm{mg} / \mathrm{dl}$ & 14 & 77,8 & 13 & 72,2 \\
\hline \multicolumn{5}{|l|}{ Kadar trigliserida } \\
\hline Normal $<150 \mathrm{mg} / \mathrm{dl}$ & 16 & 88,9 & 16 & 88,9 \\
\hline Tinggi $\geq 150 \mathrm{mg} / \mathrm{dl}$ & 2 & 11,1 & 2 & 11,1 \\
\hline \multicolumn{5}{|l|}{ Tekanan darah sistolik } \\
\hline Normal < $130 \mathrm{mmHg}$ & 14 & 77,8 & 12 & 66,7 \\
\hline Tinggi $\geq 130 \mathrm{mmHg}$ & 4 & 22,2 & 6 & 33,3 \\
\hline \multicolumn{5}{|l|}{ Tekanan darah diastolik } \\
\hline Normal $<85 \mathrm{mmHg}$ & 14 & 77,8 & 15 & 83,3 \\
\hline Tinggi $\geq 85 \mathrm{mmHg}$ & 4 & 22,2 & 3 & 16,7 \\
\hline \multicolumn{5}{|l|}{$\begin{array}{l}\text { Kadar glukosa darah } \\
\text { puasa }\end{array}$} \\
\hline Normal < 110 mg/dl & 17 & 94,4 & 17 & 94,4 \\
\hline Tinggi $\geq 110 \mathrm{mg} / \mathrm{dl}$ & 1 & 5,6 & 1 & 5,6 \\
\hline
\end{tabular}

Kadar kolesterol HDL, kadar trigliserida, tekanan darah, dan kadar glukosa darah puasa pada vegan dan non vegan sebagian besar berada dalam kategori normal. Akan tetapi, berdasarkan hasil pengukuran lingkar pinggang sebagian besar
$(61,1 \%)$ subjek non vegan berada dalam kategori obesitas sentral.

Nilai rerata, simpang baku, dan hasil uji beda komponen sindrom metabolik subjek dapat dilihat pada tabel 5 .

Tabel 5. Nilai rerata, simpang baku, dan hasil uji beda komponen sindrom metabolik

\begin{tabular}{lccc}
\hline Komponen sindrom metabolik & $\begin{array}{c}\text { Vegetarian Vegan } \\
(\mathrm{n}=18)\end{array}$ & $\begin{array}{c}\text { Vegetarian Non } \\
\text { Vegan }(\mathrm{n}=18)\end{array}$ & \multirow{2}{*}{$p$} \\
\cline { 2 - 3 } & Rerata $\pm \mathrm{SB}$ & Rerata $\pm \mathrm{SB}$ & \\
\hline Lingkar pinggang $(\mathrm{cm})$ & $77,78 \pm 8,01$ & $83,33 \pm 9,06$ & 0,060 \\
Kadar kolesterol HDL $(\mathrm{mg} / \mathrm{dl})$ & $58,04 \pm 13,33$ & $57,39 \pm 10,73$ & 0,873 \\
Kadar trigliserida $(\mathrm{mg} / \mathrm{dl})^{*}$ & $86,59 \pm 40,70$ & $88,83 \pm 45,15$ & 0,937 \\
$\begin{array}{l}\text { Tekanan darah sistolik } \\
\text { (mmHg) }\end{array}$ & $112,89 \pm 15,89$ & $128,00 \pm 17,37$ & $0,010^{* *}$ \\
$\begin{array}{l}\text { Tekanan darah diastolik } \\
\text { (mmHg) }\end{array}$ & $74,06 \pm 12,45$ & $75,78 \pm 9,67$ & 0,646 \\
$\begin{array}{l}\text { Kadar glukosa darah puasa } \\
(\mathrm{mg} / \mathrm{dl})^{*}\end{array}$ & $90,74 \pm 18,74$ & $101,79 \pm 28,54$ & $0,011^{* *}$ \\
\hline
\end{tabular}

Hasil uji independent t-test. *Uji Mann-Whitney. ${ }^{* * S i g n i f i k a n ~}(\mathrm{p}<0,05)$. 
Terdapat perbedaan tekanan darah sistolik $(p=0,010)$ dan kadar glukosa darah puasa $(p=0,011)$ antara subjek vegan dan non vegan. Sementara tidak terdapat perbedaan lingkar pinggang $(p=0,060)$, kadar kolesterol HDL $(p=0,873)$, kadar trigliserida $(p=0,937)$, dan tekanan darah diastolik $(p=0,646)$ antara vegan dan non vegan. Walaupun secara deskriptif dapat dilihat bahwa rerata kadar trigliserida, tekanan darah diastolik, dan lingkar pinggang yang lebih rendah, serta kadar kolesterol HDL yang lebih tinggi terdapat pada subjek vegan.

Berdasarkan banyaknya jumlah komponen sindrom metabolik abnormal pada masing-masing subjek, dapat diketahui subjek tersebut mengalami sindrom metabolik atau tidak mengalami sindrom metabolik. Hasil uji beda sindrom metabolik antara vegan dan non vegan ditunjukkan oleh tabel 6 .

Tabel 6. Hasil uji beda sindrom metabolik antara vegan dan non vegan

\begin{tabular}{|c|c|c|c|c|c|c|c|}
\hline \multirow{3}{*}{$\begin{array}{l}\text { Tipe } \\
\text { vegetarian }\end{array}$} & \multicolumn{6}{|c|}{ Subjek dengan jumlah komponen sindrom metabolik abnormal ${ }^{18}$} & \multirow{3}{*}{$p$} \\
\hline & \multicolumn{2}{|c|}{ Tidak ada komponen } & \multicolumn{2}{|c|}{1 atau 2 komponen } & \multicolumn{2}{|c|}{$\geq 3$ komponen } & \\
\hline & $\mathrm{n}$ & $\%$ & $\mathrm{n}$ & $\%$ & $\mathrm{n}$ & $\%$ & \\
\hline Vegan & 9 & 50,0 & 7 & 38,9 & 2 & 11,1 & \\
\hline $\begin{array}{l}\text { Non } \\
\text { vegan }\end{array}$ & 5 & 27,8 & 11 & 61,1 & 2 & 11,1 & $\begin{array}{c}0,76 \\
6\end{array}$ \\
\hline Total & 14 & 38,9 & 18 & 50,0 & 4 & 11,1 & \\
\hline
\end{tabular}

Terdapat dua subjek $(11,1 \%)$ baik pada kelompok vegan maupun non vegan yang mengalami sindrom metabolik. Separuh (50\%) subjek vegan tidak memiliki komponen sindrom metabolik abnormal, sedangkan pada subjek non vegan sebagian besar $(61,1 \%)$ memiliki satu atau dua komponen sindrom metabolik abnormal. Namun, hasil uji statistik menunjukkan bahwa tidak terdapat perbedaan sindrom metabolik antara vegetarian vegan dan non vegan $(p=0,766)$.

\section{PEMBAHASAN}

\section{Karakteristik Subjek Penelitian}

Usia dan jenis kelamin memegang peranan penting dalam kejadian sindrom metabolik yang termasuk dalam faktor yang tidak dapat dimodifikasi. ${ }^{19}$ Prevalensi sindrom metabolik meningkat seiring dengan peningkatan usia. Risiko sindrom metabolik umumnya meningkat setelah usia 40 tahun. Penelitian di Amerika Serikat menunjukkan bahwa kejadian sindrom metabolik meningkat persentasenya menjadi $37,2 \%$ pada kelompok umur 40-59 tahun dan 54,4\% pada kelompok umur $\geq 60$ tahun. $^{6}$ Pemilihan wanita sebagai subjek penelitian dikarenakan terdapat perbedaan komposisi lemak tubuh antara wanita dan pria, dimana wanita cenderung memiliki komposisi lemak tubuh yang lebih tinggi dibanding pria pada kelompok usia yang sama. ${ }^{20}$ Subjek dalam penelitian ini adalah usia dewasa dengan rentang usia antara 20-65 tahun, dimana rerata usia non vegan lebih tinggi daripada vegan.

\section{Perbedaan Sindrom Metabolik Subjek}

Penelitian Rizzo et al menunjukkan bahwa vegetarian cenderung mempunyai komponen sindrom metabolik yang lebih baik dan risiko sindrom metabolik yang lebih rendah dibanding non vegetarian. ${ }^{10}$ Hasil penelitian menunjukkan hal yang serupa dimana prevalensi kejadian sindrom metabolik pada vegetarian baik vegan maupun non vegan dalam penelitian ini sebesar $11,1 \%$, jauh lebih rendah dibanding prevalensi sindrom metabolik pada non vegetarian dengan kelompok umur dan jenis kelamin yang sama yaitu sebesar 13,3\%. ${ }^{21}$ Prevalensi yang lebih rendah ini dikarenakan asupan vegetarian tinggi asam lemak tidak jenuh dan serat yang diketahui mempunyai efek protektif terhadap sindrom metabolik. ${ }^{2}$

Subjek vegan maupun non vegan yang mengalami sindrom metabolik pada penelitian ini berada pada kelompok usia lebih dari 60 tahun, dimana pada usia tersebut wanita telah memasuki usia menopause. Pada wanita menopause, terjadi perubahan fisiologis akibat dari penurunan kuantitas hormon esterogen yang menyebabkan prevalensi sindrom metabolik pada wanita periode menopause lebih besar dibanding periode premenopause. Menopause dikaitkan dengan perubahan penting dalam berat badan dan distribusi lemak tubuh. Wanita postmenopause cenderung menambah berat badan mulai tahun pertama dari menopause dan mendistribusi lemak tubuh dari tipe gynoid ke android. Peningkatan lemak tubuh ini sering dikaitkan dengan perubahan 
negatif dari resistensi insulin, lipid plasma, dan tekanan darah yang dapat meningkatkan risiko sindrom metabolik..$^{19,22}$

Berdasarkan hasil uji statistik, tidak terdapat perbedaan kejadian sindrom metabolik antara wanita vegetarian vegan dan non vegan. Namun secara deskriptif, rerata komponen sindrom metabolik (lingkar pinggang, kadar kolesterol HDL, kadar trigliserida, tekanan darah, dan kadar glukosa darah puasa) pada vegan lebih baik dibanding non vegan, walaupun sebagian besar subjek vegan dalam penelitian ini baru menjalankan diet vegan kurang dari 6 tahun dan mempunyai aktivitas fisik yang lebih rendah dibanding non vegan. Penelitian yang membahas hubungan antara lama menjadi vegetarian dengan komponen sindrom metabolik masih terbatas. Konsumsi jangka panjang dari diet vegetarian yang rendah kalori dan rendah protein dikaitkan dengan penurunan beberapa komponen sindrom metabolik, seperti tekanan darah dan profil lipid. Namun, dasar mekanisme yang menjelaskan hubungan ini juga belum diketahui secara pasti. ${ }^{14}$ Aktivitas fisik juga diketahui memiliki efek protektif terhadap sindrom metabolik melalui peningkatan kadar kolesterol HDL, penurunan kadar trigliserida atau keduanya. Selain itu, peningkatan aktivitas fisik juga berhasil dalam menurunkan tekanan darah, meningkatkan toleransi glukosa, sensitivitas insulin, dan menurunkan risiko diabetes tipe 2. ${ }^{9}$ Dengan kata lain, apabila lama menjadi vegan setara dengan sebagian besar subjek non vegan (> 11 tahun) dan aktivitas fisik subjek vegan ditingkatkan maka komponen sindrom metabolik pada vegan akan lebih baik lagi dan mungkin komponen sindrom metabolik abnormal yang ditemukan pada vegan akan dapat dihilangkan.

Pada penelitian ini didapatkan $61,1 \%$ subjek non vegan yang mengalami obesitas sentral dengan lingkar pinggang lebih dari $80 \mathrm{~cm}$. Peningkatan kejadian sindrom metabolik sejalan dengan peningkatan obesitas sentral, sehingga lingkar pinggang dapat digunakan untuk mendeteksi sindrom metabolik. Penelitian yang menghubungkan hal ini telah banyak dilakukan, dan sebagian besar peneliti menyimpulkan bahwa lemak viseral (obesitas sentral) lebih kuat hubungannya dengan sindrom metabolik dibandingkan lemak subkutan atau lemak tubuh total (obesitas). ${ }^{23},{ }^{24}$ Jaringan lemak viseral memiliki aktivitas yang tinggi baik pada lipogenesis maupun lipolisis, dimana akumulasi ini menginduksi peningkatan kandungan asam lemak bebas. Kelebihan asam lemak bebas dapat menyebabkan peningkatan sintesis lemak dan glukoneogenesis serta resistensi insulin yang mengakibatkan hiperlipidemia, intoleransi glukosa, dan hipertensi. ${ }^{25}$

\section{SIMPULAN}

Tidak terdapat perbedaan kejadian sindrom metabolik antara wanita vegetarian tipe vegan dan non vegan. Namun, komponen sindrom metabolik yang terdiri dari lingkar pinggang, kadar kolesterol HDL, kadar trigliserida, tekanan darah, dan kadar glukosa darah puasa pada vegan lebih baik daripada non vegan walaupun sebagian besar subjek baru menjalankan diet vegan kurang dari enam tahun dan mempunyai aktivitas fisik yang lebih rendah dibanding non vegan.

\section{SARAN}

Berkaitan dengan hasil penelitian ini, dimana vegetarian murni (vegan) diketahui mempunyai komponen sindrom metabolik yang lebih baik dibanding non vegan. Peneliti dapat menyarankan kepada masyarakat yang mempunyai masalah kesehatan terkait sindrom metabolik, dapat mencoba untuk melakukan perubahan dari pola makan yang biasanya ke diet vegetarian tipe vegan dan disertai dengan peningkatan aktivitas fisik untuk hasil yang lebih maksimal.

\section{DAFTAR PUSTAKA}

1. Susianto. Analisis faktor-faktor yang berhubungan dengan IMT/U pada balita vegetarian lakto ovo dan non vegetarian di DKI Jakarta tahun 2008. [Tesis]. Jakarta: Universitas Indonesia. 2008. Available http://gizi.net/makalah/download/tesis_susianto.pd f [accessed on February 24th, 2012].

2. Sabaté J, Ratzin-Turner RA, Brown JE. Vegetarian diet: descriptions and trends. In: Joan Sabaté, editor. Vegetarian nutrition. USA: CRC Press LLC; 2001. p. 3-17.

3. Whitney E, Rolfes SR. Understanding nutrition, 11th edition. USA: Thomson Wadsworth. 2008; p. 64-67.

4. Grundy SM, Brewer HB, Cleeman JI, Smith SC, Lenfant C. Definition of metabolic syndrome: report of the National Heart, Lung, and Blood Institute/American Heart Association conference on scientific issues related to definition. Circulation AHA 2004;109: 433-8.

5. Grundy SM, Cleeman JI, Daniels SR, Donato KA, Eckel RH, Franklin BA, et al. Diagnosis and 
management of the metabolic syndrome: an American Heart Association/National Heart, Lung, and Blood Institute scientific statement. Circulation AHA 2005;112: 2735-52.

6. Ervin RB. Prevalence of metabolic syndrome among adults 2- years of age and over, by sex, age, race, and ethnicity, and body mass index: United States, 2003-2006. National Health Statistics Reports 2009;13:1-8.

7. Ford ES, Giles WH, Mokdad AH. Increasing prevalence of the metabolic syndrome among U.S. adults. Diabetes Care 2004;27(10): 2444-9.

8. Pande DM, Suastika K, Saraswati IMR, Gotera W, Budhiarta AAG, Sutanegara, et al. Prevalensi sindroma metabolik pada populasi penduduk Bali. J Peny Dalam 2011;12(1): 1-5.

9. Delavar MA, Sann LM, Hassan STBS, Lin KG, Hanachi P. Physical activity and the metabolic syndrome in middle aged women, Babol, Mazandaran province, Iran. European Journal of Scientific Research 2008;22(3): 411-21.

10. Rizzo NS, Sabaté J, Jaceldo-Siegi K, Fraser GE. Vegetarian dietary patterns are associated with a lower risk of metabolic syndrome. Diabetes Care 2011;34: 1225-7.

11. Shang P, Shu Z, Wang Y, Li N, Du S, Sun F, et al. Veganism does not reduce the risk of the metabolic syndrome in Taiwanese cohort. Asia Pac J Clin Nutr 2011;20(3): 404-10.

12. Fraser GE. Risk factors and disease among vegans. In: Fraser $G$, editor. Diet, life expectancy, and chronic disease.Studies of Seventh-day Adventists and other vegetarians. New York: Oxford University Press; 2003. p. 231-9.

13. De Biase SG, Fernandes SFC, Gianini RJ, Duarte JLG. Vegetarian diet and cholesterol and triglycerides levels. Arq Bras Cardiol 2007; 88(1): 32-36.

14. Yang SY, Zhang HJ, Sun SY, Wang LY, Yan B, Liu CQ, et al. Relationship of carotid intima-media thickness and duration of vegetarian diet in Chinese male vegetarians. Nutrition \& Metabolism 2011;8:63.

15. International Physical Activity Questionnaire. Guidelines for data processing and analysis of the International Physical Activity Questionnaire (IPAQ). Short and Long Form. Revised November 2005. Available at : www.ipaq.ki.se [accessed on May 22th, 2012].

16. Soegondo S, Reno G. Sindrom metabolik. In: Sudoyo AW, Setiyohadi B, Alwi I, Simadibrata M, Setiati S, editors. Buku ajar ilmu penyakit dalam. Edisi ke-4. Jakarta: Pusat Penerbitan Departemen Ilmu penyakit Dalam Fakultas Kedokteran Universitas Indonesia; 2006. p. 1849-51.

17. Dahlan MS. Statistika untuk kedokteran dan kesehatan: deskriptif, bivariat, dan multivariat, dilengkapi aplikasi menggunakan SPSS. Jakarta: Salemba Medika; 2008. p. 82-142.

18. Yoo S, Nicklas T, Baranowski T, Zakeri IF, Yang SJ, Srinivasan SR, et al. Comparison of dietary intakes associated with metabolic syndrome risk factors in young adults: the Bogalusa Heart Study. Am J Clin Nutr 2004;80: 841-8.

19. Krummel DA. Medical nutrition therapy in cardiovascular disease. In: Mahan LK and Stump SE. Krause's food and nutrition therapy 12th edition. Pennsylvania: Saunders; 2008. p. 833-64.

20. Szymanska JO, Wozniak EH, Platkowska I, Malara M. Effect of age, gender, and physical activity on plasma lipid profile. Biomedical Human Kinetics 2011;3:1-5.

21. Nestel P, Lyu R, Low LP, Sheu WH-H, Nitiyanant W, Saito I, et al. Metabolic syndrome: recent prevalence in East and Southeast Asian populations. Asia Pac J Clin Nutr 2007;16(2): 3627.

22. Rosano GMC, Vitale C, Fini M. Hypertension in postmenopausal women. European Endocrine Disease 2006: 1-6.

23. National Cholesterol Education Program. Third report of the National Cholesterol Education Program (NCEP) expert panel on detection, evaluation, and treatment of high blood cholesterol in adult (adult treatment panel III). Final report. Circulation AHA 2002;106: 3143-421.

24. Janssen I, Heymsfield SB, Allison DB, Kotler DP, Ross R. Body mass index and waist circumference independently contribute to the prediction of nonabdominal, abdominal subcutaneous, and visceral fat. Am J Clin Nutr 2002;75: 683-8.

25. Li X, Katashima M, Yasumasu T, Li KJ. Visceral fat area, waist circumference and metabolic risk factors in abdominally obese Chinese adults. Biomed Environ Sci 2012;25(2): 141-8. 